\title{
Enhancement Production of Phenolic Compounds in The Cell Suspension Culture of Iberis Amara L.: The Effect of Chitosan Elicitation
}

Marzieh Taghizadeh

University of Isfahan

Marzieh Sabagh Nekonan

Isfahan Science and Technology Town

Mahbubeh Setorki ( $\sim$ Doctor.setorgi@gmai.com )

Islamic Azad University of Izeh

\section{Research Article}

Keywords: Chitosan, Cell suspension culture, Medicinal herbs, Secondary metabolite.

Posted Date: August 23rd, 2021

DOI: https://doi.org/10.21203/rs.3.rs-785230/v1

License: (c) (i) This work is licensed under a Creative Commons Attribution 4.0 International License.

Read Full License 


\section{Abstract}

Iberis amara L. medicinal herb is well-known for having pharmacological values although its use has been challenged by the low levels of secondary metabolites. To address this issue, this study focused on evaluating the effect of explant, photoperiod, and plant growth regulators (PGRs) to find the optimum medium for inducing callus and establishing cell suspension in $I$. amara, followed by investigating the chitosan effect on some secondary metabolites. From our observations, the optimum condition for induced callus was achieved from the leaf explants in Murashige and Skoog (MS) media completed with $3 \mathrm{mg} \mathrm{L}^{-1}$ 6-benzylaminopurine(BAP) and $1 \mathrm{mgL}^{-1}$ 1-naphthalene acetic acid(NAA) under 16-h light/8-h dark photoperiod. The MS enhanced with $3 \mathrm{mgL}^{-1} \mathrm{BAP}, 1 \mathrm{mg} \mathrm{L}^{-1} \mathrm{NAA}$, and $2 \%(\mathrm{w} / \mathrm{v})$ sucrose appeared to be optimum conditions for suspension establishment. Thus, the cells were exposed to different concentrations of chitosan $\left(200,100,50\right.$, and $\left.0 \mathrm{mg} \mathrm{L}^{-1}\right)$ in their exponential growth stage from day 8 to 12 and day 12 to 16 following sub-cultures (T1) and sub-cultures (T2), respectively. The results showed that the $50 \mathrm{mgL}^{-1}$ chitosan significantly improved the total phenol, flavonoid, flavonol, and anthocyanin content in the I. amara in a dose-dependent manner. The highest malondialdehyde (MDA) amount, as a result of lipid peroxidation, was observed under the $200 \mathrm{ppm}$ chitosan elicitation. Overall, these novel findings demonstrated the possibility of applying the cell suspension of I. amara treated with chitosan as a helpful approach for improving synthesizing phenolic compounds under controlled and sterile conditions without genetic modifications in medicinal herbs.

\section{Introduction}

Medicinal herbs have long been known for producing secondary metabolites, which are utilized as bioactive compounds in pharmaceutical applications (Gonçalves and Romano 2018). Iberis amara L. (I. amara), as a genus of the family Brassicaceae native to southern Europe, has been used by ancient humans in order to cure rheumatism and some other diseases. This medicinal herb is also well-known beneficial for restoring health from bronchitis, asthma, and cardiac hypertrophy (Liu et al. 2020). A phytomedicine (i.e., Iberogast ${ }^{\circledR}$ ) has recently been provided from the I. amara herb extract and applied to relieve the symptoms of gastrointestinal disturbances related to irritable bowel syndrome and functional dyspepsia (Golkar and Moattar 2019). Such a therapeutic value has been attributed to the presence of some natural products that are available in the aerial part of medicinal herbs. I. amara has a large pool of bioactive ingredients including triterpenes, glucosinolates (Weidner et al. 2016), amines, flavonoids, anthocyanins, flavones, and phenolic acids (Golkar and Moattar 2019). There are some reports on its use in traditional medicine as an anti-cancer (Weidner et al. 2016), anti-inflammatory (Khayyal et al. 2015), antioxidant and antimicrobial plant (Schempp et al. 2003).

Despite a large amount of information regarding the therapeutic value of $I$. amara, this herb meets low levels of bioactive products, which strongly depends on bio-physiological and environmental conditions (Liu et al. 2020). Therefore, plant tissue and cell suspension culture appear as a viable biotechnological tool for the production of secondary metabolites in medicinal plants. These techniques have been applied 
for increasing the quantity and quality of drugs and provide a promising bio-production platform for a desired natural product (Dias et al. 2016; Khvatkov et al. 2015; Yue et al. 2016). A variety of elicitors as chemical compounds stimulating the signaling pathways were suggested as an innovative tool for the improvement of natural product biosynthesis (Taghizadeh et al. 2021b). A number of elicitor compounds have so far been adopted to modulate cell metabolism and increase bioactive ingredients in cell culture media (Qiu et al. 2021; Ramirez-Estrada et al. 2016). Biotic elicitors with microorganism origins such as chitosan have been exhibited to increase the plant metabolites having therapeutic values (Qiu et al. 2021). Chitin and its deacetylated derivative (i.e., chitosan) also play a critical role in activating resistance against pathogens in plants (Putalun et al. 2007). It is considered as a biotic elicitor that induces phytoalexin accumulations in plant tissues (Orlita et al. 2008). Elicitors have so far been applied for improving the content of biologically valuable ingredients (Udomsuk et al. 2011) and providing a highthroughput platform for producing natural products in vitro (Chakraborty et al. 2009). For instance, Khan et al. (2002) observed that chitin and chitosan oligomers increased the activity of tyrosine/phenylalanine ammonia-lyase (TAL and PAL) in soybean plants, resulting in a $50 \%$ increase in phenolic compounds. Similarly, Govindaraju and Arulselvi (2018) reported a higher percentage of tannins, terpenoids, saponins, and alkaloids in in vitro Coleus aromaticus regenerated plants. Likewise, Putalun et al. (2007) reported a dose-dependent 6 -fold increase in artemisinin accumulations by subjecting Artemisia annua L. to $150 \mathrm{mg}$ $\mathrm{I}^{-1}$ chitosan.

To the best of our knowledge, there are no reports on the establishment of cell suspension culture and the effect of chitosan on the accumulation of secondary metabolites in I. amara. This study is the first one to focus on optimizing a high-throughput procedure for inducing callus and establishing cell suspension in I. amara, as well as using chitosan to enhance the content of phenols, flavonoids, flavonols, and anthocyanins. This understanding can lead to the introduction of a new way to improve the production yield of beneficial phenolic metabolites from undifferentiated $I$. amara cells.

\section{Material And Methods}

\subsection{Plant materials and optimization of germination medium}

I. amara seeds were provided from the Gol Daroo Co. and then transferred to the lab for determining their best germination medium. To sterilize, the seeds were treated with $70 \%$ alcohol for 60 s as well as $2 \%$ $\mathrm{NaOCl}$ solution for $20 \mathrm{~min}$, and eventually washed in sterile water three times. After sterilization being carried out, the seeds were placed on MS base (Murashige and Skoog 1962) medium containing $5 \mathrm{mg} \mathrm{L}^{-}$

${ }^{1} \mathrm{GA} 3,0.8 \%(\mathrm{w} / \mathrm{v})$ agar and $3 \%(\mathrm{w} / \mathrm{v})$ sucrose at $\mathrm{pH}$. Eventually, the seeds were incubated at $25 \pm 1{ }^{\circ} \mathrm{C}$ under the $16 \mathrm{~h} \mathrm{light/8} \mathrm{h}$ dark photoperiod in the growth chambers.

\subsection{Optimization of callus induction}


For callus induction, the explants of $I$. amara were obtained from in vitro grown plants on the MS medium. Four weeks after the growth of buds in vitro in the completely sterile conditions, two explants including 6-7 $\mathrm{mm}$ stem and leaf sections were prepared and placed on MS medium with four treatments

as follows: $2 \mathrm{mg} \mathrm{L}^{-1} 2,4 \mathrm{D} ; 1 \mathrm{mg} \mathrm{L}{ }^{-1} \mathrm{NAA}+3 \mathrm{mg} \mathrm{L}^{-1} \mathrm{BAP} ; 1 \mathrm{mg} \mathrm{L}^{-1} \mathrm{BAP}+3 \mathrm{mg} \mathrm{L}^{-1} \mathrm{NAA} ; 3 \mathrm{mg} \mathrm{L}^{-1} \mathrm{BAP}$. Explants were cultured on MS medium without PGRs were considered as a control. The explants were incubated at $25 \pm 1{ }^{\circ} \mathrm{C}$ and humidity $60 \%$ under $16 \mathrm{~h}$ light/8h dark photoperiod in the growth chamber.

\subsection{Relative Callus growth rate}

We measured the callus growth rate (CGR) and callus induction percent $(\mathrm{Cl})$. For $\mathrm{Cl}$ calculation, the relation below was used for measuring callus induction: $[(\mathrm{n} / \mathrm{N}) \times 100]$, following completion of sixth week from the callus induction initiation. " $N$ " represents the cultured explants' total number and " $n$ " denotes the callus explants' total number. For calculating CGR, the means of CGRs $\left(\mathrm{mm} \mathrm{day}^{-1}\right)$ at every two weeks was used in a two-month period (Afshar and Golkar 2016).

\subsection{Suspension culture establishment}

To determine an optimum cell suspension culture, friable callus $(2.5 \mathrm{~g})$ was moved into $100 \mathrm{~mL}$ flasks comprising $25 \mathrm{~mL}$ MS medium containing $1 \mathrm{mg} \mathrm{L}^{-1} \mathrm{NAA}+3 \mathrm{mg} \mathrm{L}^{-1}$ BAP augmented by $2 \%(\mathrm{w} / \mathrm{v})$ sucrose. Then incubated in darkness on gyratory shakers at $125 \mathrm{rpm}$. The subculture of cell suspension was carried out at steady intervals of 14 days on the fresh media.

\subsection{The curve of cell growth}

After being isolated from the suspension culture through filtration, $2.5 \mathrm{~g}$ of fresh cells were cultured in 25 $\mathrm{mL}$ MS within $100 \mathrm{~mL}$ flasks. Cell growth was followed with flasks harvested at two days intervals from the day of subculture (0th day) until cell weight was stable (24th day). The weight of the samples was measured and recorded by a digital scale. According to the plotted growth curve, the best time to harvest cells was selected.

\subsection{Elicitor treatment}

To elicit the biosynthetic pathway of natural products in I. amara, the chitosan with $50 \mathrm{k}$ Da molecular weight (Sigma-Aldrich, Germany) was dissolved in 3\% ( $/ / v)$ acetic acid $(0.1 \mathrm{M})$ through mild heating and continuing mixing at $55^{\circ} \mathrm{C}$ for $8 \mathrm{~h}$. The eventual concentration of chitosan was adjusted to $10 \mathrm{mg} \cdot \mathrm{mL}^{-1}$. To further dissolve chitosan, the solution was mixed and autoclaved for 20 minutes at $121^{\circ} \mathrm{C}$, and kept at $4^{\circ} \mathrm{C}$. In the exponential growth stage, we exposed the cells to chitosan at the varying concentrations $(0$, 50,100 , and $200 \mathrm{mg} \mathrm{L}^{-1}$ ), which was performed from day 8 to 12 following sub-cultures (T1) and day 12 to 16 following sub-cultures (T2). Some empirical studies and reviewed literature were used as the basis for selection of the elicitation period and concentrations (Chong et al. 2005; Khan et al. 2003; Taghizadeh et al. 2019)

When elicitations were finished, we harvested the cells from the suspension cultures by filtration. For this purpose, a Buchner funnel was utilized with a nylon mesh in frozen and vacuum state in liquid $\mathrm{N}_{2}$, and it 
was maintained at $-80^{\circ} \mathrm{C}$ for subsequent biochemical surveys.

\subsection{Cell growth assay}

In order to measure the cell growth, cells were collected after treatment and rinsed with distilled water twice. The fresh weight was then measured using a digital scale.

\subsection{Cells extraction process}

Firstly, cells were perfectly dried, and then 200 of them were ground in liquid N. Afterward, the cells were homogenized with methanol ( $3 \mathrm{~mL})$, followed by centrifuging for $15 \mathrm{~min}$ at $10000 \mathrm{rpm}$. The supernatant was then gathered and maintained at $-20^{\circ} \mathrm{C}$ for the subsequent analysis.

\subsection{Total phenol content Determination}

To estimate total phenol content, the methanolic extract $(0.5 \mathrm{ml})$ was supplemented with $1.5 \mathrm{ml}$ of $10 \%$ Folin-Ciocalteu reagent and $1.5 \mathrm{ml}$ of $15 \%$ sodium carbonate, and eventually kept at $25^{\circ} \mathrm{C}$ for $90 \mathrm{~min}$. The solution absorbance was read at $725 \mathrm{~nm}$ by using a spectrophotometer. The total content of phenolic compounds was estimated according to the gallic acid standard in mg gallic acid equivalent per $\mathrm{g}$ of cell dry weight (Taghizadeh et al. 2019).

\subsection{Flavonoid and flavonol content Determination}

Total flavonol and flavonoid contents were determined via the aluminum chloride procedure, as elucidated by Tahsili et al., (2014). For total flavonol, $3 \mathrm{~mL}$ of sodium acetate, $1 \mathrm{~mL}$ of methanolic extract, and $1 \mathrm{~mL}$ of aluminum chloride were mixed together. The absorbance for each mixture was determined at $445 \mathrm{~nm}$. For total flavonoid, $250 \mu \mathrm{L}$ of potassium acetate, $1 \mathrm{~mL}$ of methanolic extract, and $250 \mu \mathrm{L}$ of aluminum chloride were mixed and remained at $25 \pm 1^{\circ} \mathrm{C}$ for 30 min to read the absorbance at $415 \mathrm{~nm}$. Rutin was utilized as the standard for the calibration curve. The content of total flavonol and flavonoid was presented as $\mathrm{mg}$ rutin per $\mathrm{g}$ of dry weight.

\subsection{Anthocyanin content Determination}

To measure the anthocyanin content, according to Hara et al. (2003), $200 \mathrm{mg}$ of dried cells was ground in $3 \mathrm{ml}$ of acidic methanol (99: 1 ratio of ethanol to acetic acid), and then the resulted extract was carefully centrifuged at $12000 \mathrm{rpm}$ for $20 \mathrm{~min}$. The supernatant was placed in the dark overnight after filtration and its absorption was recorded by using a spectrophotometer at $511 \mathrm{~nm}$. To calculate the concentration of anthocyanins, $\mathrm{M}^{-1} \mathrm{~cm}^{-1} 33000$ extinction coefficient was exerted and the anthocyanin accumulation was presented in nmol per $\mathrm{g}$ of dry weight.

\subsection{Lipid peroxidation determination}

MDA was measured for determining the cell membrane damage and lipid peroxidation. MDA was the end product of membrane lipids' peroxidation. Therefore, $0.1 \%$ trichloroacetic acid (TCA) solution was used for homogenizing the samples. We centrifuged the homogenate at $10000 \mathrm{rpm}$, and then collected 
supernatant. The process was followed by mixing supernatant $(500 \mu \mathrm{L})$ with $0.5 \%$ thiobarbituric acid (TBA) $(2 \mathrm{~mL})$ and $20 \%$ TCA. Then, the sample was warmed for $30 \mathrm{~min}$ at $95^{\circ} \mathrm{C}$, and it was swiftly chilled in the ice bath. A spectrophotometer was used for measuring the sample's absorbance at 600 and 532 $\mathrm{nm}$. The extinction coefficient used for quantifying the amount of MDA was $155 \mathrm{mM}^{-1} \mathrm{~cm}^{-1}$, and it was presented as $\mu \mathrm{mol} \mathrm{g}{ }^{-1} \mathrm{FW}$ (Heath and Packer 1968).

\subsection{Statistical analysis}

The current study was performed as a factorial experiment in a completely-randomized design (CRD) with three repeats. Analysis of variance and mean comparison (LSD at $P \leq 0.05$ ) were accomplished through SAS software V. 9.1 (SAS Institute Inc.). The differences among means were represented as mean \pm standard error.

\section{Results And Discussion}

\subsection{Optimum callus induction medium}

Although I. amara is a significant medical herb, there is no study on using in vitro cultures of this plant. The signs of callus production were observed approximately 12-14 days after transferring stem and leaf explants to medium compositions.

The results of the analysis of variance (ANOVA) indicated the statistically significant impact of plant growth regulators (PGRs), types of explant, photoperiod, and interactions with studied traits (data are not presented). Based on the findings, light significantly affected I. amara callus growth (CGR, $\mathrm{Cl})$ as compared to dark conditions. In addition, visual symptoms revealed that the induction, formation, and growth of callus in 16-h light/8-h dark photoperiod was highly better than the conditions of absolute darkness. As a result, further analyses were applied only on 16-h light/8-h dark photoperiod. According to previous reports, this phenomenon (i.e., light effect) may be associated with the crosstalk between light signaling and IAA hormone (Rikiishi et al. 2008), photo-regulation modulated by phytochromes (Garcia et al. 2011), and/or the effect of light on the photosynthetic pathway stimulation, chloroplast differentiation, ethylene evolution, and cell division rate (Garcia et al. 2011). These findings suggest that light modulates I. amara traits in vitro by physiological changes. Similar observations with 16-h light/8-h dark photoperiod for improving callus induction and callus growth rate were previously recorded for $D$. polychaetum and D. kotschyi (Taghizadeh et al. 2020).

The mean interactions in a completely randomized design were compared since the interactions of PGRs and explants were significant. Table 1 presents the effects of different PGRs (MS, MS $+2 \mathrm{mg} \mathrm{L}^{-1} 2,4 \mathrm{D}$, $\mathrm{MS}+1 \mathrm{mg} \mathrm{L}^{-1} \mathrm{NAA}+3 \mathrm{mg} \mathrm{L}^{-1} \mathrm{BAP}, \mathrm{MS}+1 \mathrm{mg} \mathrm{L}^{-1} \mathrm{BAP}+3 \mathrm{mg} \mathrm{L}^{-1} \mathrm{NAA}$, and $\left.\mathrm{MS}+3 \mathrm{mg} \mathrm{L}^{-1} \mathrm{BAP}\right)$ and explants (leaf and stem) on callus induction (\%) and callus growth rate of $I$. amara. As previously mentioned, this is the first report regarding the optimized protocol for callus induction in $I$. amara. Our findings showed no callus induction on the MS medium, as a control, for two explants. Based on the 
results, $2 \mathrm{mg} \mathrm{L}^{-1}$ 2,4 $\mathrm{D}$ and $3 \mathrm{mg} \mathrm{L}^{-1}$ BAP represent an inhibitory influence on callus production thus they were excluded from further analyses. The completed MS medium with $3 \mathrm{mg} \mathrm{L}^{-1} \mathrm{BAP}$ and $1 \mathrm{mg} \mathrm{I}^{-1} \mathrm{NAA}$ was found to be the appropriate culture medium for the highest callus induction (85.16\%) in the leaf explant of I. amara (Table 1). The least values for $\mathrm{Cl}(27.17 \%)$ and $(25 \%)$ were denoted to leaf and stem explants at the MS medium supplemented by $3 \mathrm{mgL}^{-1} \mathrm{NAA}+1 \mathrm{mgL}^{-1} \mathrm{BAP}$ (Table 1). Leaf explants were detected to be suitable for callus induction so that they induced large calluses in the culture medium (Fig. 1). As observed in the recent work, the callus induction from the leaf/stem explant relied on the combination and concentration of PGRs. Accordingly, the optimal level of exogenous PGRs is vital for $\mathrm{Cl}$ in I. amara. Four treatments were compared, and it was shown that BAP concentrations (as cytokinin) were higher compared to NAA and 2,4D (as auxins), which might promote a higher frequency in $\mathrm{Cl}$ and growth in I. amara. Similar observations with NAA and BAP hormones for improving callus induction were previously recorded in some herbs (Hajati et al. 2016; Taghizadeh et al. 2020). Based on the findings (Table 1), leaf explants with the enhanced MS medium with $3 \mathrm{mgL}^{-1} \mathrm{BAP}$ and $1 \mathrm{mgL}^{-1} \mathrm{NAA}$ demonstrated the largest CGR $\left(0.32 \mathrm{~mm}\right.$ day $\left.^{-1}\right)$ while leaf and stem explants at the enhanced MS medium with $3 \mathrm{mgL}^{-1} \mathrm{NAA}$ and $1 \mathrm{mgL}^{-1}$ BAP indicated the smallest CGR $\left(0.08 \mathrm{~mm}\right.$ day $\left.{ }^{-1}\right)$. Therefore, there was a positive interactive impact for NAA and BAP concentrations on the employed explant for the callus growth enhancement. PGR is a crucial factor that is responsible for $\mathrm{Cl}$ and growth in plant cell cultures. PGR optimal concentration could rely on various factors including genotype of plant, endogenous PGR concentration of explants, and the origin of explants (Mathur and Shekhawat 2013; Taghizadeh et al. 2020). According to previous reports, auxins and cytokinins are commonly employed in the culture of plant tissues for callus induction (Garcia et al. 2011; Taghizadeh et al. 2020). 
Table 1

The effects of combination of different plant growth regulators (PGRs) on the callus induction (CI) and callus growth rate (CGR) of I. amara.

\begin{tabular}{|llll|}
\hline Explants & PGRs & Cl (\%) & CGR (mmday $\left.{ }^{-1}\right)$ \\
\hline Leaf & $\mathrm{MS}+\mathrm{NAA}\left(1 \mathrm{mg} \mathrm{L}^{-1}\right)+\mathrm{BAP}\left(3 \mathrm{mg} \mathrm{L}^{-1}\right)$ & $¥ 85.16^{\mathrm{a}} \pm 7.89$ & $0.32^{\mathrm{a}} \pm 0.08$ \\
\hline Stem & $\mathrm{MS}+\mathrm{NAA}\left(1 \mathrm{mg} \mathrm{L}^{-1}\right)+\mathrm{BAP}\left(3 \mathrm{mg} \mathrm{L}^{-1}\right)$ & $70.13^{\mathrm{b}} \pm 6.75$ & $0.21^{\mathrm{b}} \pm 0.05$ \\
\hline Leaf & $\mathrm{MS}+\mathrm{NAA}\left(3 \mathrm{mg} \mathrm{L}^{-1}\right)+\mathrm{BAP}\left(1 \mathrm{mg} \mathrm{L}^{-1}\right)$ & $25.00^{\mathrm{c}} \pm 14.02$ & $0.08^{\mathrm{C}} \pm 0.06$ \\
\hline Stem & $\mathrm{MS}+\mathrm{NAA}\left(3 \mathrm{mg} \mathrm{L}^{-1}\right)+\mathrm{BAP}\left(1 \mathrm{mg} \mathrm{L}^{-1}\right)$ & $25.17^{\mathrm{c}} \pm 9.26$ & $0.1^{\mathrm{c}} \pm 0.09$ \\
\hline Leaf & $\mathrm{MS}+2,4 \mathrm{D}\left(2 \mathrm{mg} \mathrm{L}^{-1}\right)$ & - & - \\
\hline Stem & $\mathrm{MS}+2,4 \mathrm{D}\left(2 \mathrm{mg} \mathrm{L}^{-1}\right)$ & - & - \\
\hline $\begin{array}{l}\text { Leaf } \\
\text { Stem }\end{array}$ & $\mathrm{MS}+\mathrm{BAP}\left(3 \mathrm{mg} \mathrm{L}^{-1}\right)$ & - & - \\
\hline $\begin{array}{l}¥ \text { Data are the mean of four replicates; the values with the same superscript letters are not statistically } \\
\text { different at } P \leq 0.05 \text { significance level according to LSD test. }\end{array}$ & \\
\hline
\end{tabular}

\subsection{Optimum suspension establishment medium}

According to our observations, l. amara cells could not grow on the suspension media having $3 \%(\mathrm{w} / \mathrm{v})$ sucrose after transferring the callus. In similar studies, Khanpour-Ardestani et al., (2015) and Taghizadeh et al., (2020) observed that high sucrose levels in the culture medium generally led to low biomass accumulations. It seems that the cell growth is stopped through high osmotic pressure and/or relatively high initial concentrations of sucrose (Mathur and Shekhawat 2013). Based on this recommendation, the sucrose concentration was reduced to $2 \%(\mathrm{w} / \mathrm{v})$. The MS medium supplemented with $1 \mathrm{mg} \mathrm{L}^{-1} \mathrm{NAA}, 3$ $\mathrm{mg} \mathrm{L}^{-1} \mathrm{BAP}$, and $2 \%(\mathrm{w} / \mathrm{v})$ sucrose at a $\mathrm{pH}$ of 6 appeared to be optimum conditions for suspension establishment according to visual symptoms. Regarding diverse responses to hormones, it can be concluded that PGRs are critical factors that are responsible for $I$. amara suspension establishment in cell culture. From previous reports, the advisable concentration of these hormones is dependent on explant type, genotype, and explant origin (Mathur and Shekhawat 2013; Taghizadeh et al. 2020).

\subsection{Cell growth curve}

The findings represented that cell growth was extremely low in the first five days (the delayed phase). The exponential growth of these cells was recorded from the 6th to 16th day after inoculation (the logarithmic phase). The highest fresh weight of cells was observed on the 16th day, which increased approximately four folds. Then, the cells entered the dormant phase for about four days and the cell growth stopped (the dormant phase). Eventually, the weight of the cells decreased and the cells entered the death phase 
(Fig. 2). Therefore, the times for treatment application were considered at the beginning (8-12th day) and middle (12-16th day) of the logarithmic growth stage. These findings open a time window toward the use of cell suspension culture to produce phenolic compounds, flavonoids, flavonols, and anthocyanins, which acquired a pharmacological value.

\subsection{Fresh weight}

The results of analysis of variance showed that the chitosan elicitations, period time of elicitation, and different interactions had a significant effect on all the studied traits (data known show). Based on the results, the maximum fresh weight $\left(10.3 \mathrm{~g}\right.$ ) was detected in both control cells and $50 \mathrm{mg} \mathrm{L}^{-1}$ chitosantreated cells on the 12-16th day after the harvest (Fig. 3a). The minimum fresh weight $(6.22 \mathrm{~g})$ was detected in $200 \mathrm{mg} \mathrm{L}^{-1}$ chitosan-treated cells on the 8-12th day (Fig. 3a). The stressor effects of high concentrations of chitosan (100 and $200 \mathrm{ppm}$ ) reduced the cell fresh weight, which could be resulted from the inhibitory effects of elicitors on cell growth and the capacity of cell osmotic adjustment, increasing the requirement for maintaining the turgor of the growing cells, consuming energy, and decreasing cell growth. Additionally, other negative effects of chitosan in higher concentrations may be related to damaged cell division and cell membrane (Rikiishi et al. 2008). Likewise, higher concentrations of chitosan in safflower reduced the callus fresh weight (Golkar et al. 2019). Similar observations were reported by Udomsuk et al. (2011) and Talukder et al. (2016) (Talukder et al. 2016) on Pueraria candollei and Plantago ovata, respectively. Thereby, $50 \mathrm{mg} \mathrm{L}^{-1}$ chitosan was determined as the most favorable concentration for maintaining the cell fresh weight in I. amara.

\subsection{Lipid peroxidation}

MDA is a product of lipid peroxidation that indicates free-radical accumulations and oxidative stress. Improved membrane permeability and disrupted membrane integrity were possible reasons for the induction of oxidative stress (Taghizadeh et al. 2020). Further, the content of MDA increased remarkably in the cells that were elicited with 100 and 200 ppm chitosan compared with the control (Fig. 3b). The largest increase in the MDA amount to 3.93 and $3.87 \mu \mathrm{mol} . \mathrm{g}^{-1} \mathrm{FW}$ was observed under $200 \mathrm{ppm}$ chitosan-treated cells on the 12-16th day and 8-12th elicitation, indicating a nearly 2-fold increase in comparison with that of the control cells. In the present research, the increment of MDA content (Fig. 3b) indicated that high chitosan concentrations might have a direct impact on the cell membrane functions and structures. The oxidative stress also induced disruption in the integrity of the membrane, leading to increased permeability of the cell membrane (Taghizadeh et al. 2019). Consequently, the cells could not hinder the peroxidation of membrane lipids. The increment of MDA content is in agreement with the decrease in fresh weight that was observed under 200 ppm chitosan-treated cells. In fact, high concentrations of chitosan caused the development of free oxygen radicals (reactive oxygen species, ROSs) and oxidative stress, and thus could directly disrupt cell membrane structures and eventually, caused cell death and fresh weight losses. The lipid peroxidation levels demonstrated no significant difference in control and cells with $50 \mathrm{ppm}$ chitosan elicitation. The observed differences in the values of MDA at $50 \mathrm{ppm}$ chitosan were not significant probably due to the supplementary impacts of higher accumulations of phenolics at chitosan elicitation via ROS detoxification and membrane integrity 
protection. The effectiveness of secondary metabolites (e.g., phenolics) in the deceleration of lipid peroxidation is attributed to their free radical-scavenging ability (Taghizadeh et al. 2019). The lipid peroxidation might also mediate signal transduction resulting in the increased generation of secondary metabolites. Other works indicated an increase of lipid peroxidation in Acer pseudoplatanus L. cultured cells under the chitosan elicitation (Malerba and Cerana 2015).

\subsection{Total phenol content}

According to previous reports, elicitors can enhance the level of phenolic compounds through a rapid increment in the activity of key enzymes responsible for biosynthetic pathways, including PAL (Govindaraju and Arulselvi 2018). Thus, the interaction effect of different concentrations and treatment intervals of chitosan were investigated to retest this output in I. amara (Fig. 3c). Based on the evidence, $50 \mathrm{mg} \mathrm{L}^{-1}$ chitosan on the 12-16th day after inoculation led to a greater increase in the total phenol accumulation when compared to other treatments and control. The total phenol compounds significantly increased approximately 1.22 fold from the control condition (1.22 $\mathrm{mg} \mathrm{GA} \mathrm{g}^{-1} \mathrm{DW}$ ) up to 34.1 (mg GA g ${ }^{1} \mathrm{DW}$ ) when calli were treated with $50 \mathrm{mg} \mathrm{L}^{-1}$ chitosan (Fig. 3c). Many studies demonstrated the strong relationship between plant secondary metabolism and plant defense responses (Taghizadeh et al. 2021a). The effectiveness of secondary metabolites such as phenolic compounds in the deceleration of lipid peroxidation is attributed to their free radical-scavenging ability (Taghizadeh et al. 2019). Phenolic compounds could act as Fenton reaction inhibitors and iron chelators or could directly eliminate free radicals and reduce oxidative damage (Manquián-Cerda et al. 2016; Maqsood et al. 2014). The higher phenolic compounds might protect plant cells under the chitosan elicitation and show interference with the signaling cascade in plant cell responses. Consistent with the findings of the present research, it was reported that the phenol content derived from phenylpropanoid pathways is induced as a result of in vitro chitosan application in Coleus aromaticus (Govindaraju and Arulselvi 2018) and Carthamus tinctorius (Golkar et al. 2019). Khan et al. (2003) also proved an about 50\% augmentation in the total phenol amount in the soybean plants following chitosan treatment, displaying a positive correlation between PAL activity and the total phenol content. Considering that PAL is a vital enzyme in the phenylpropanoid biosynthetic pathway, it seems that its overactivity resulted in more phenol accumulations in chitosantreated I. amara (Khan et al. 2003).

\subsection{Flavonoid content}

Flavonoid accumulation in plants has a major role in protecting plants encountered with biotic and abiotic damages (Alrawaiq and Abdullah 2014). Flavonoids are the key components of the antioxidant system with subgroups as flavonols and anthocyanins (Falcone Ferreyra et al. 2012). The treatment of $I$. amara cells on the 12-16th day after inoculation with $50 \mathrm{mg} \mathrm{L}^{-1}$ chitosan resulted in a significant increase in the flavonoid accumulation $\left(0.94 \mathrm{mg}\right.$ rutin. $\left.\mathrm{g}^{-1} \mathrm{DW}\right)$ in contrast to other treatments and the control (Fig. 3d). In other words, the $50 \mathrm{mg} \mathrm{L}^{-1}$ chitosan caused an increase of about 2.19 folds flavonoid content rather than a non-elicited callus. Similarly, the increased content of flavonoid compounds was reported in Plantago ovata (Talukder et al. 2016), Carthamus tinctorius (Golkar et al. 2019), and Pueraria 
candollei using chitosan (Udomsuk et al. 2011). The increase in flavonoid content derived from the chitosan elicitor suggests a higher rate of flavonoid production owing to the possible positive effect of this elicitor on the expression of the gene coding enzymes engaged in the flavonoid biosynthesis (Talukder et al. 2016). In fact, increased phenolic compounds and flavonoids may protect plant cells against ROS generation in response to biotic and abiotic elicitors, and it will interfere with the signaling cascade involved in plant adaptation to environmental stresses. For instance, an improved flavonoid accumulation was reported due to the increased expression of the gene-coding PAL enzyme in the Coleus aromaticus plant (Govindaraju and Arulselvi 2018). Likewise, Chen et al. (2009) concluded that chitosan increases the expression of genes responsible for flavonoid and phenylpropanoid biosynthesis in soybean sprouts (Chen et al. 2009). Overall, the increased flavonoid content in I. amara may be related to the direct effect of $50 \mathrm{mg} \mathrm{L}^{-1}$ chitosan on gene expression, transcription factors, and activity of enzymes that are involved in the phenylpropanoid pathway.

\subsection{Flavonol content}

The highest amount of flavonol (i.e., $0.8 \mathrm{mg}$ rutin per dry weight) was detected in the cell suspension supplemented with $50 \mathrm{mg} \mathrm{L}^{-1}$ chitosan on the 12-16th day (Fig. 3e), reflecting the favorable effect of low concentrations of the chitosan elicitor on the flavonol content in I. amara cells. Conversely, the lower level of chitosan ( $\left.50 \mathrm{mg} \mathrm{L}^{-1}\right)$ was found to further accumulate flavonols compared to its higher levels. These observations are in line with the results of Talukder et al. (2016) and Govindaraju and Arulselvi (2018) on Coleus aromaticus and Coleus aromaticus, respectively. Moreover, flavonol production increased in the cell suspension of the chitosan-treated Cocos nucifera herb (Chakraborty et al., 2009). Despite such reports regarding the beneficial effects of chitosan on flavonol content, the mechanism of action and biosynthetic or signaling pathways affected by this hormone remain unknown.

\subsection{Anthocyanin content}

Given that anthocyanins have been well-known for anti-inflammatory, anti-cancer, anti-microbial, and antioxidant properties, many studies have focused on these natural products. In the current experiment, the highest amount of anthocyanin (i.e., $12.27 \mu \mathrm{mol}$ per dry weight), as a subgroup of flavonoids, was detected in the cell suspension treated with $50 \mathrm{mg} \mathrm{L}^{-1}$ on the 12-16th day (Fig. 3f). Our findings on the chitosan-derived increased content of secondary metabolites corroborate with those of Park et al. (Park et al. 2019) and Govindaraju and Arulselvi (2018) on Fagopyrum esculentum and Coleus aromaticus, respectively. The change in anthocyanin content can be attributed to the modulated activity of transcription factors responsible for the anthocyanin biosynthesis pathway, which is affected by the chitosan elicitor and/or partially by the applied plant growth regulators in the callus induction/suspension establishment media (Kim et al. 2006). Although the exact mode of action of chitosan is complicated, our findings verified the dependence of the elicitation process in vitro on elicitor concentrations. Some other factors including callus age, culture medium, plant species and genotype, and elicitor type and its exposure time can thus have a significant effect on elicitation processes (Philibert et al. 2017). 
According to our data, the contents of the total phenolics, flavonoids, flavonol, MDA, and anthocyanins in chitosan-treated cells on the 12-16th day (T2) were significantly higher than those of cells treated with chitosan on 8-12th elicitation (T1). These observations suggest that the antioxidant system is significantly stimulated by increasing the age of cells elicited by chitosan.

\subsection{Trait correlations}

Table 2 provides the obtained correlations among the evaluated traits. The total phenolic compounds indicated significant positive correlations with flavonoid and anthocyanin $\left(0.702^{\star \star}\right.$ and $\left.0.762^{\star \star}\right)$ suggested at synchronization pathways for biosynthesis and gathering these compounds in chitosan and normal elicitation (Table 3). According to these results, with higher phenolic compounds, flavonoid and anthocyanin might provide protection for plant cells against stresses and show interference with the signaling cascades in plant responses. Furthermore, such a rise could be due to the elicitation of their biosynthetic pathways, the improved enzymatic activity, and the expression of pertinent genes. There was a significant negative correlation between MDA and the total phenolic compounds $\left(-0.784^{\star \star}\right)$, flavonoid $\left(-0.456^{*}\right)$, anthocyanin $\left(-0.722^{\star \star}\right)$, and fresh weight $\left(-0.619^{\star \star}\right)$, implying that increases in all these metabolites caused a decrease in the MDA level. As mentioned earlier, MDA is a cytotoxic product of lipid peroxidation that indicates free-radical accumulations. Chitosan affects plant cells via inducing oxidative stress and increasing activity, lifetime, and concentrations of free radicals. The possible causing factor for the induction of oxidative stress disrupted membrane integrity, improved lipid peroxidation and cell toxicity, and then caused cell death (Taghizadeh et al. 2020). In other words, these compounds have possibly a vital role as free radical scavenging in I. amara cells subjected to chitosan elicitation. In this condition, cell fresh weight decreased by an increase in MDA. Therefore, this correlation represented the strong antioxidant property of total phenolic, flavonoid, and anthocyanin in ROS scavenging or detoxifying the harmful effects of elicitation. 
Table 2

Correlation coefficients among bioactive components in the $I$. amara studied under different concentration of chitosan.

\section{Total Phenolic Flavonoid Flavonol Antocyanin Fresh weight MDA}

Total Phenolic

Flavonoid

$0.752^{\star *} \quad 1$

Flavonol

\begin{tabular}{lll}
\hline $0.429^{*}$ & $0.712^{\star *}$ & 1 \\
\hline
\end{tabular}

Antocyanin

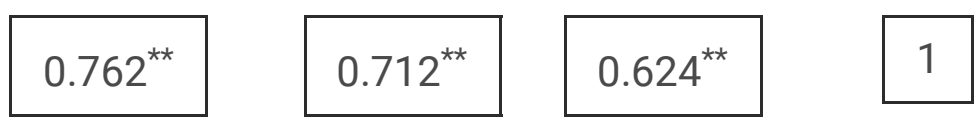

Fresh weight

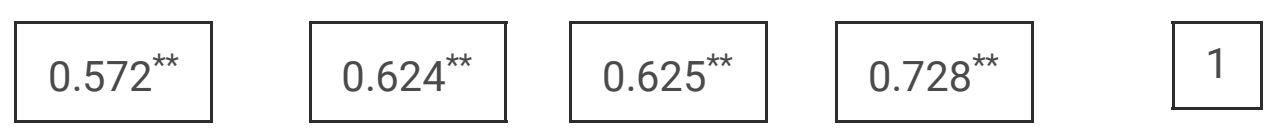

MDA

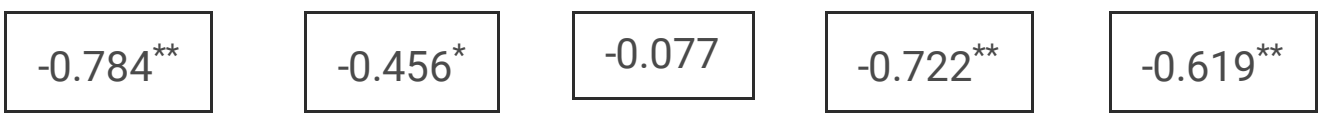

** and * Significant at $1 \%$ and $5 \%$ levels of probability, respectively.

\section{Conclusion}

In this study, the optimum in vitro conditions were obtained for inducing callus and establishing the cell suspension of the I. amara medicinal herb. The optimum medium for callus induction was provided from 
leaf and stem explants in the MS medium supplemented by $3 \mathrm{mg} \mathrm{l}^{-1}$ BAP and $1 \mathrm{mg} \mathrm{I}^{-1}$ NAA. The MS medium supplemented by $3 \mathrm{mg} \mathrm{L}^{-1} \mathrm{BAP}, 1 \mathrm{mg} \mathrm{L}^{-1} \mathrm{NAA}$, and $2 \%(\mathrm{w} / \mathrm{v})$ sucrose at a $\mathrm{pH}$ of 6 was found suitable for achieving rapid-growing suspension cells. Interestingly, $50 \mathrm{mg} \mathrm{I}^{-1}$ chitosan remarkably improved the phenol, flavonoid, flavonol, and anthocyanin content in the I. amara medicinal herb in a dose-dependent way. As a result, chitosan (50 ppm) was detected as an efficient elicitor for enhancing secondary metabolites in $I$. amara and probably other medicinal herbs. The results of the present work can pave the way for improving the generation of beneficial medicinal compounds from undifferentiated cells in a vulnerable medicinal herb called I. amara.

\section{Declarations}

\section{Acknowledgments}

The authors would like to extend their gratitude to the Kara Pajouhesh Company, Isfahan Science and Technology Town, Isfahan, Iran for their financial support. The authors would like to thank Izeh University, Izeh, and University of Isfahan, Isfahan, Iran.

\section{Author Contribution}

M. T. and M. S. devised the project, the main conceptual ideas and proof outline. M. T. and M. S. N. developed the theory. M. T. carried out the experiment and collected data. M. T verified the analytical methods, M. T. and M. S. analyzed and interpreted the data. M. T. wrote the manuscript. M. T., M. S. N. and M. S. contributed to the final version of the manuscript. All authors supervised the project and discussed the results and contributed to the final manuscript.

\section{Conflict of Interest}

The authors declare that they have no conflict of interest.

\section{References}

1. Afshar B, Golkar P (2016) Mucilage synthesis by in vitro cell culture in different species of Alyssum BioTechnologia Journal of Biotechnology Computational Biology and Bionanotechnology 97

2. Alrawaiq NS, Abdullah A (2014) A review of flavonoid quercetin: metabolism, bioactivity and antioxidant properties. Int J PharmTech Res 6:933-941

3. Chakraborty M, Karun A, Mitra A (2009) Accumulation of phenylpropanoid derivatives in chitosaninduced cell suspension culture of Cocos nucifera. Journal of plant physiology 166:63-71

4. Chen H, Seguin P, Archambault A, Constan L, Jabaji S (2009) Gene expression and isoflavone concentrations in soybean sprouts treated with chitosan. Crop Sci 49:224-236

5. Chong TM, Abdullah MA, Lai OM, Nor'Aini FM, Lajis NH (2005) Effective elicitation factors in Morinda elliptica cell suspension culture. Process Biochem 40:3397-3405 
6. Dias MI, Sousa MJ, Alves RC, Ferreira IC (2016) Exploring plant tissue culture to improve the production of phenolic compounds: A review Industrial. Crops Products 82:9-22

7. Falcone Ferreyra ML, Rius S, Casati P (2012) Flavonoids: biosynthesis, biological functions, and biotechnological applications Frontiers in plant science 3:222

8. Garcia R, Pacheco G, Falcao E, Borges G, Mansur E (2011) Influence of type of explant, plant growth regulators, salt composition of basal medium, and light on callogenesis and regeneration in Passiflora suberosa L.(Passifloraceae) Plant Cell. Tissue Organ Culture (PCTOC) 106:47-54

9. Golkar P, Moattar F (2019) Essential Oil Composition, Bioactive Compounds, and Antioxidant Activities in Iberis amara. L Natural Product Communications 14:1934578X19846355

10. Golkar P, Taghizadeh M, Yousefian Z (2019) The effects of chitosan and salicylic acid on elicitation of secondary metabolites and antioxidant activity of safflower under in vitro salinity stress Plant Cell. Tissue Organ Culture (PCTOC) 137:575-585

11. Gonçalves S, Romano A (2018) Production of plant secondary metabolites by using biotechnological tools Secondary metabolites, sources and applications, IntechOpen:81-99

12. Govindaraju S, Arulselvi PI (2018) Effect of cytokinin combined elicitors (I-phenylalanine, salicylic acid and chitosan) on in vitro propagation, secondary metabolites and molecular characterization of medicinal herb-Coleus aromaticus Benth $(\mathrm{L})$. Journal of the Saudi Society of Agricultural Sciences 17:435-444

13. Hajati RJ, Payamnoor V, Bezdi KG, Chashmi NA (2016) Optimization of callus induction and cell suspension culture of Betula pendula Roth for improved production of betulin, betulinic acid, and antioxidant activity In Vitro Cellular \& Developmental Biology-Plant 52:400-407

14. Hara M, Oki K, Hoshino K, Kuboi T (2003) Enhancement of anthocyanin biosynthesis by sugar in radish (Raphanus sativus) hypocotyl. Plant Sci 164:259-265

15. Heath RL, Packer L (1968) Photoperoxidation in isolated chloroplasts: I. Kinetics and stoichiometry of fatty acid peroxidation. Arch Biochem Biophys 125:189-198

16. Khan W, Prithiviraj B, Smith DL (2003) Chitosan and chitin oligomers increase phenylalanine ammonia-lyase and tyrosine ammonia-lyase activities in soybean leaves. Journal of plant physiology 160:859-863

17. Khanpour-Ardestani N, Sharifi M, Behmanesh M (2015) Establishment of callus and cell suspension culture of. Scrophularia striata Boiss: an in vitro approach for acteoside production Cytotechnology 67:475-485

18. Khayyal MT, Agha AM, Zaki HF, El-Sahar A, Abdel-Aziz H (2015) Mechanisms involved in the antiinflammatory and vascular effects of Iberis amara. extract Planta medica 81:1097-1102

19. Khvatkov P, Chernobrovkina M, Okuneva A, Shvedova A, Chaban I, Dolgov S (2015) Callus induction and regeneration in Wolffia arrhiza (L.) Horkel ex Wimm Plant Cell. Tissue Organ Culture (PCTOC) 120:263-273

20. Kim J-S, Lee B-H, Kim S-H, Oh K-H, Cho KY (2006) Responses to environmental and chemical signals for anthocyanin biosynthesis in non-chlorophyllous corn (Zea mays L.) leaf. Journal of Plant Biology 
49:16-25

21. Liu X-y, Ou H, Gregersen H (2020) Ultrasound-assisted supercritical CO2 extraction of cucurbitacin E from Iberis amara seeds Industrial Crops and Products 145:112093

22. Malerba M, Cerana R (2015) Reactive oxygen and nitrogen species in defense/stress responses activated by chitosan in sycamore cultured cells. Int J Mol Sci 16:3019-3034

23. Manquián-Cerda K, Escudey M, Zúñiga G, Arancibia-Miranda N, Molina M, Cruces E (2016) Effect of cadmium on phenolic compounds, antioxidant enzyme activity and oxidative stress in blueberry (Vaccinium corymbosum L.) plantlets grown in vitro. Ecotoxicol Environ Saf 133:316-326

24. Maqsood S, Benjakul S, Abushelaibi A, Alam A (2014) Phenolic compounds and plant phenolic extracts as natural antioxidants in prevention of lipid oxidation in seafood: A detailed review. Comprehensive Reviews in Food Science Food Safety 13:1125-1140

25. Mathur S, Shekhawat GS (2013) Establishment and characterization of Stevia rebaudiana (Bertoni) cell suspension culture: an in vitro approach for production of stevioside. Acta Physiol Plant 35:931939

26. Murashige T, Skoog F (1962) A revised medium for rapid growth and bio assays with tobacco tissue cultures. Physiol Plant 15:473-497

27. Orlita A et al (2008) Application of chitin and chitosan as elicitors of coumarins and furoquinolone alkaloids in Ruta graveolens L.(common rue. Biotechnol Appl Chem 51:91-96

28. Park CH, Yeo HJ, Park YE, Chun SW, Chung YS, Lee SY, Park SU (2019) Influence of chitosan, salicylic acid and jasmonic acid on phenylpropanoid accumulation in germinated buckwheat (Fagopyrum esculentum Moench) Foods 8:153

29. Philibert T, Lee BH, Fabien N (2017) Current status and new perspectives on chitin and chitosan as functional biopolymers Applied. biochemistry biotechnology 181:1314-1337

30. Putalun W, Luealon W, De-Eknamkul W, Tanaka H, Shoyama Y (2007) Improvement of artemisinin production by chitosan in hairy root cultures of Artemisia annua. L Biotechnology letters 29:11431146

31. Qiu H, Su L, Wang H, Zhang Z (2021) Chitosan elicitation of saponin accumulation in Psammosilene tunicoides hairy roots by modulating antioxidant activity, nitric oxide production and differential. gene expression Plant Physiology and Biochemistry

32. Ramirez-Estrada K, Vidal-Limon H, Hidalgo D, Moyano E, Golenioswki M, Cusidó RM, Palazon J (2016) Elicitation, an effective strategy for the biotechnological production of bioactive high-added value compounds in plant cell factories Molecules 21:182

33. Rikiishi K, Matsuura T, Maekawa M, Takeda K (2008) Light control of shoot regeneration in callus cultures derived from barley (Hordeum vulgare L.). immature embryos Breeding science 58:129-135

34. Schempp H, Totha A, Weiser D, Elstner EF (2003) Antioxidative properties of Iberis amara extracts in biochemical model reactions Arzneimittelforschung 53:568-577 
35. Taghizadeh M, Nasibi F, Kalantari KM, Benakashani F (2020) Callogenesis optimization and cell suspension culture establishment of Dracocephalum polychaetum Bornm. and Dracocephalum kotschyi Boiss.: An in vitro approach for secondary metabolite production South African Journal of Botany 132:79-86

36. Taghizadeh M, Nasibi F, Kalantari KM, Ghanati F (2019) Evaluation of secondary metabolites and antioxidant activity in Dracocephalum polychaetum Bornm. cell suspension culture under magnetite nanoparticles and static magnetic field elicitation Plant Cell. Tissue Organ Culture (PCTOC) 136:489-498

37. Taghizadeh M, Nasibi F, Kalantari KM, Mohseni-Moghadam M (2021a) Modification of phytochemical production and antioxidant activity of Dracocephalum kotschyi cells by exposure to static magnetic field and magnetite nanoparticles Plant Cell, Tissue and Organ Culture (PCTOC):113

38. Taghizadeh M, Nasibi F, Mohseni-Moghadam M (2021b) Modification of Phytochemical Production and Antioxidant Activity of Dracocephalum Kotschyi Cells by Exposure. to Static Magnetic Field and Magnetite Nanoparticles

39. Tahsili J, Sharifi M, Safaie N, Esmaeilzadeh-Bahabadi S, Behmanesh M (2014) Induction of lignans and phenolic compounds in cell culture of Linum album by culture filtrate of Fusarium graminearum. Journal of plant interactions 9:412-417

40. Talukder P, Talapatra S, Ghoshal N, Sen Raychaudhuri S (2016) Antioxidant activity and highperformance liquid chromatographic analysis of phenolic compounds during in vitro callus culture of Plantago ovata Forsk. and effect of exogenous additives on accumulation of phenolic compounds. $J$ Sci Food Agric 96:232-244

41. Udomsuk L, Jarukamjorn $K$, Tanaka H, Putalun W (2011) Improved isoflavonoid production in Pueraria candollei hairy root cultures using elicitation. Biotechnol Lett 33:369-374

42. Weidner C, Rousseau M, Plauth A, Wowro SJ, Fischer C, Abdel-Aziz H, Sauer S (2016) Iberis amara extract induces intracellular formation of reactive oxygen species and inhibits colon cancer. PLoS One 11:e0152398

43. Yue W, Ming Q-I, Lin B, Rahman K, Zheng C-J, Han T, Qin L-p (2016) Medicinal plant cell suspension cultures: pharmaceutical applications and high-yielding strategies for the desired secondary metabolites. Crit Rev Biotechnol 36:215-232

\section{Figures}




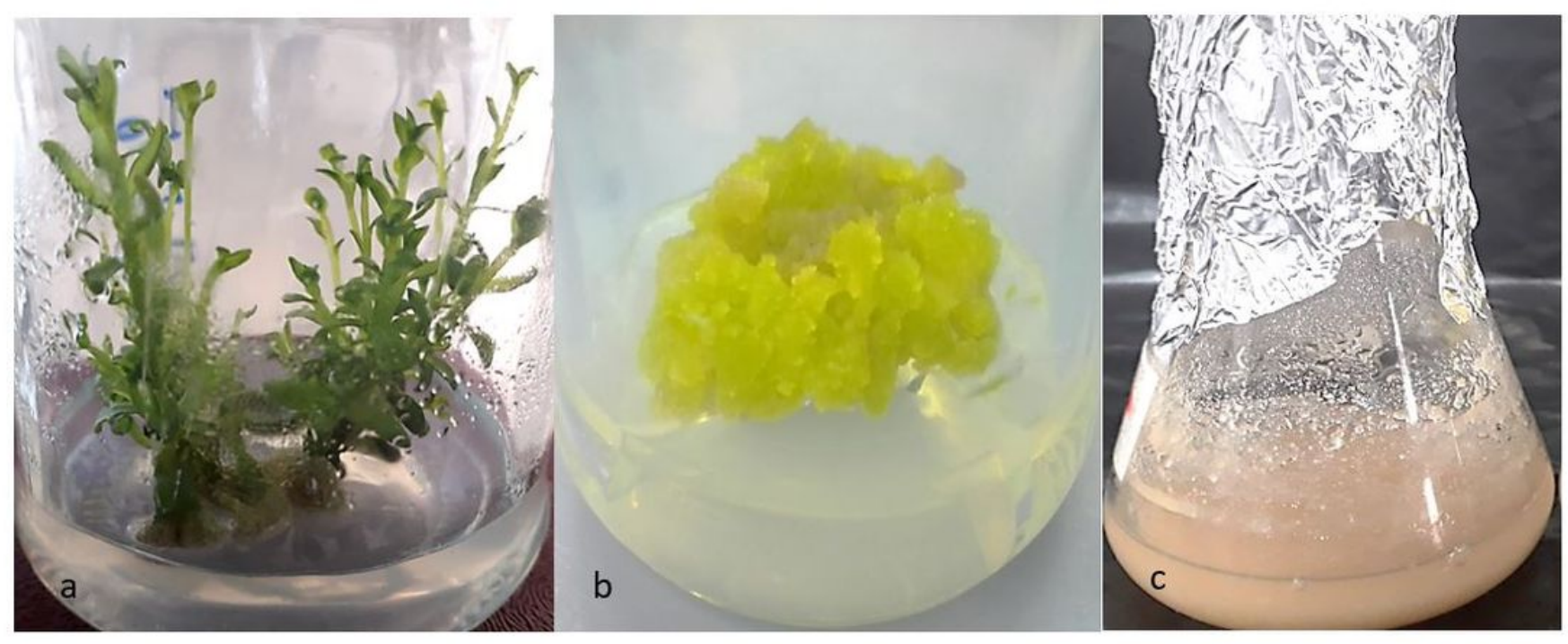

Figure 1

Seedlings grown in Murashige and Skoog medium (a); Leaf explant-derived callus in MS medium completed with 1mg L-1 NAA and 3mg L-1 BAP (b); Establishment of suspension-cultured I. amara cells in MS medium with $1 \mathrm{mg}$. L-1 NAA, 3 mg. L-1 BAP (c).

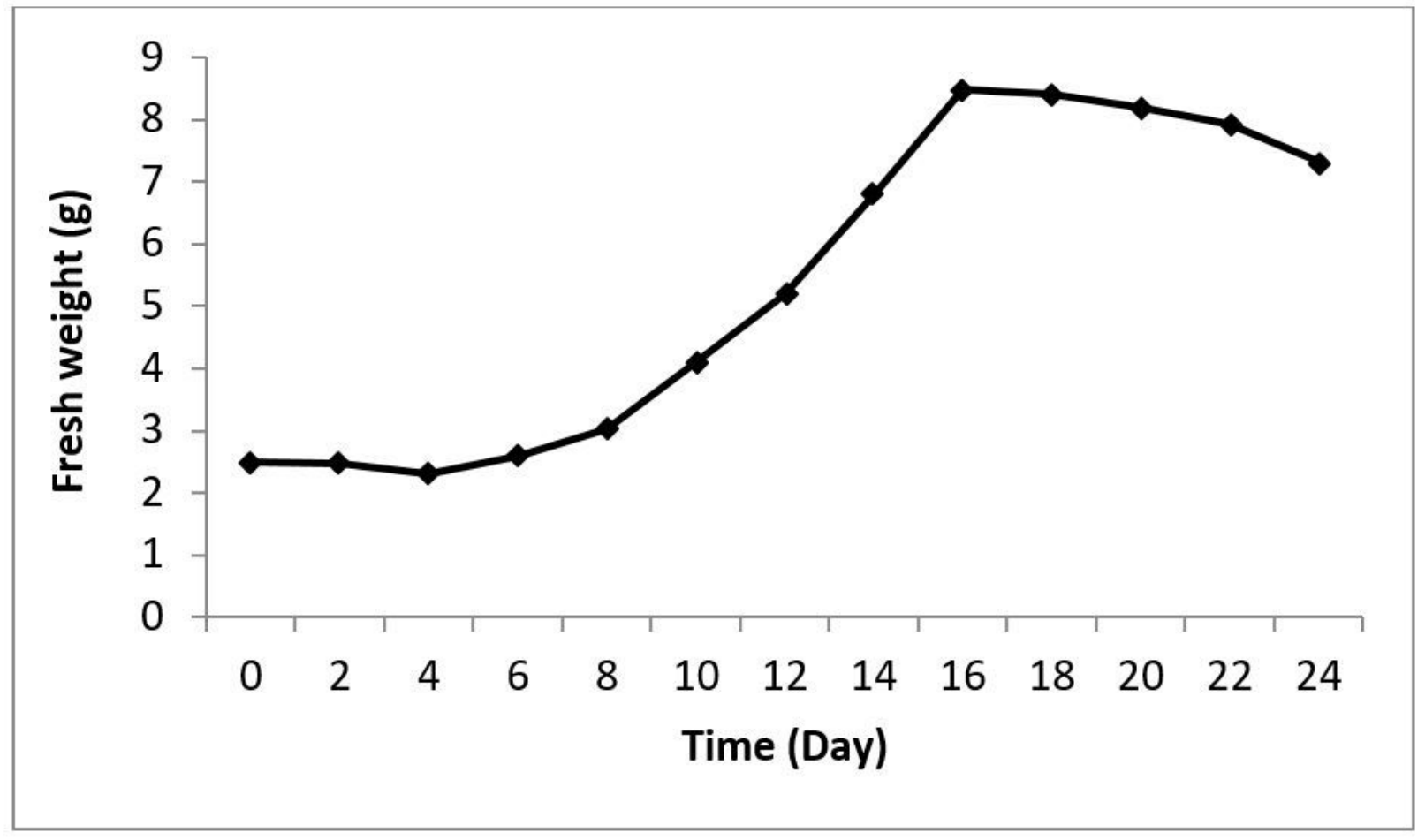


Figure 2

Growth curve of suspension-cultured I. amara cells during 24 days of incubation in MS medium augmented with $1 \mathrm{mg} \mathrm{L}-1 \mathrm{NAA}$ and $3 \mathrm{mg}$ L-1 BAP.
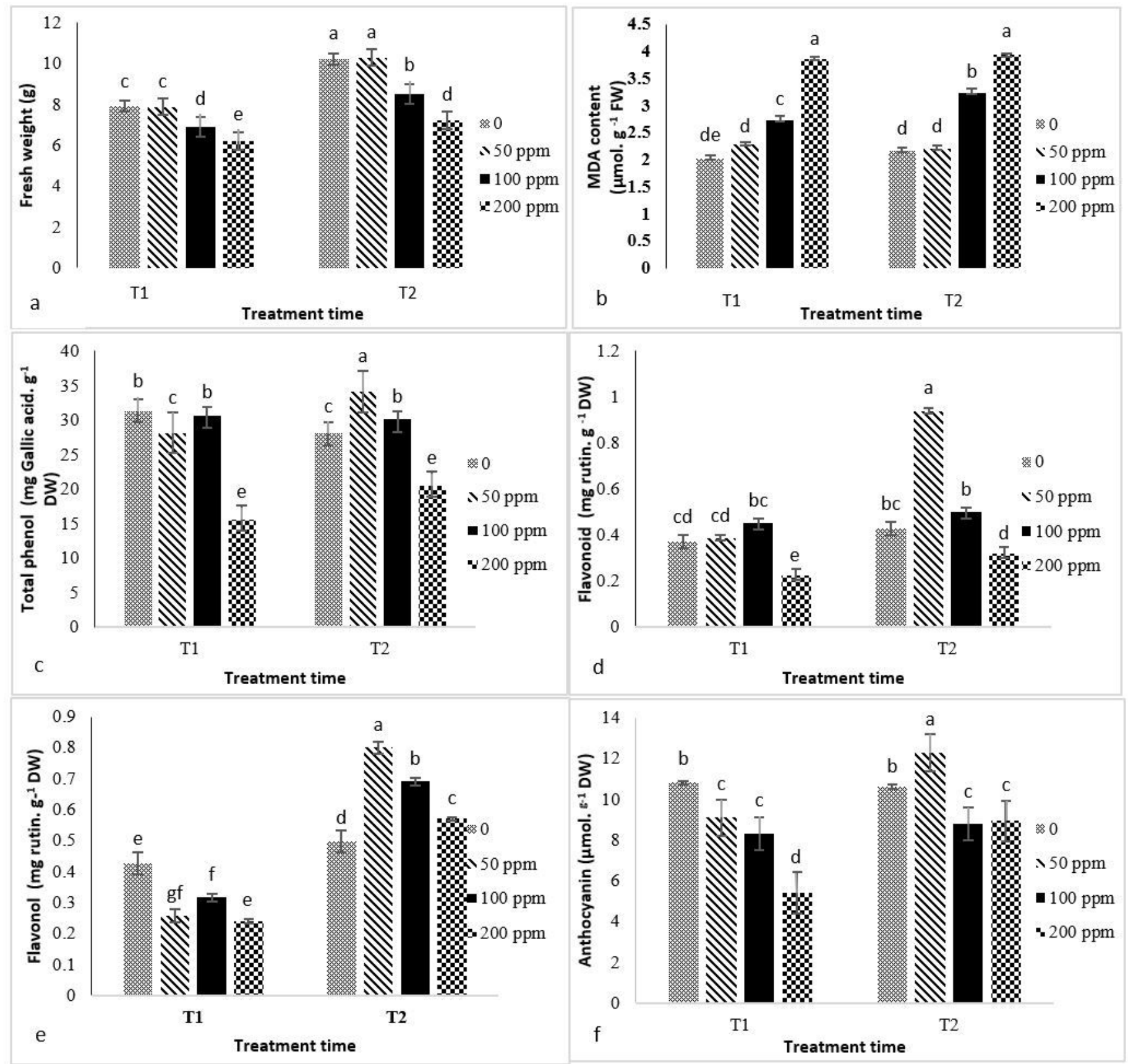

Figure 3

Effect of treatment intervals and chitosan concentrations on fresh weight (a); MDA content (b); phenolic compounds (c); flavonoid (d); flavonol (e); anthocyanin (f) of I. amara cells. T1: A group of cells treated from 8th to 12th day after inoculation, T2: A group of cells treated from 12th to 16th day after 
inoculation. Different letters demonstrate significant differences at the $\mathrm{P}<0.05$ level according to LSD test. The values were shown as mean \pm SE. 